\title{
The impact of different commercial probiotic cultures with starters on technological, physicochemical and sensorial properties of a traditional yogurt-based appetizer "Cacık"
}

\author{
Seda Altuntas ${ }^{1 *}$, Mihriban Korukluoglu²
}

\author{
'Bursa Technical University, Faculty of Natural Sciences and Engineering, \\ Department of Food Engineering, 16310, Bursa, Turkey, \\ 2Uludağ University, Faculty of Agriculture, Department of Food Engineering, 16059, Bursa, Turkey \\ *Corresponding author: E-mail: seda.altuntas@btu.edu.tr
}

\section{Abstract}

The selection of proper probiotic culture is essential for maintaining adequate numbers of viable cells until consumption since potential adverse interaction between selected strain and starter culture. This study examined the suitability of Cacık as a potential probiotic carrier including Lactobacillus acidophilus 74-2, Lactobacillus rhamnosus Howaru $\mathrm{HNOO1}^{\mathrm{TM}}$ and Bifidobacterium longum BB536 in different combinations. The presence of three probiotic strains caused higher post acidification and shorter fermentation time associated to higher counts of L. bulgaricus. Except for certain combinations containing B. longum BB536, the counts of individual probiotic bacteria were higher than $6 \mathrm{log} \mathrm{g}^{-1}$ for all probiotic supplemented Cacık samples. Results showed that bacterial interaction was decisive for survival over 21 days of storage. Probiotic products containing only B. longum BB536 or B. longum BB536 with L. acidophilus 74-2 did not accomplish in terms of the technological point, since the viable cell counts decerased for $2.45 \mathrm{log}$ and $1.95 \mathrm{log}$ per g, respecitevly, throughout the storage period. In three of totally four combinations included L. rhamnosus Howaru HNOO1 ${ }^{\mathrm{TM}}$ alone or combined with other probiotic bacteria, the viable cell counts of L. rhamnosus Howaru HNOO1 ${ }^{\mathrm{TM}}$ remained at the inoculated level, while the counts significantly increased in co-culture with L. acidophilus 74-2. Considering the overall sensorial attributes and survival of probiotics, Cacık supplemented with L. rhamnosus Howaru HNOO1 ${ }^{\mathrm{TM}}$ alone, combinations of B. longum BB536 and L. rhamnosus Howaru HNO01 ${ }^{\mathrm{TM}}$ or L. acidophilus 74-2 and L. rhamnosus Howaru HNOO1 ${ }^{\mathrm{TM}}$ or by all of the three tested probiotics, were suggested as suitable for further production.

Key words: probiotic, survival, interaction, yogurt-based appetizer, additives

\section{Introduction}

Traditional products have gained importance by majority of consumers in recent years. Cacık is a traditional product that is made by adding small diced cucumber, crushed garlic, mint and salt into a stirred type yogurt and consumed to feel relieved in the summer months. Cacık, which is usually served 
beside the main dish in the Turkish cuisine, has got different flavours and names because of the cross-cultural interaction located in the nearby geography. It is called "Talatur" in Cyprus, "Tzatziki" in Greece, "Jajeek" in Iraq and "Tarator" in Balkan countries and they include almost similar ingredients with Cacık (Tsiraki and Savvaidis, 2014).

Dairy products are an excellent vehicle to carry probiotic microorganisms that have been well documented in terms of providing health benefits. The remaining high dose of probiotic cells as possible as before expiration date in products is the main challenging issue for food technologists. Besides, probiotics are preferred using in combination with starter culture due to slow growth and correspondingly poor acidity during fermentation and long incubation times varying from 8 to 24 hours that cannot be applied to the industry. Additionally, the unpleasant flavours might be produced by the growth of undesirable microorganisms until the probiotics become dominant (Mohammadi et al., 2012). The necessity of coexistence of probiotic and starter cultures leads to a new problem that restricts the selection of probiotic strains, since there might occur a potentially adverse interaction between the selected strain and the starter culture that directly affects the maintaining of adequate numbers of viable cells until consumption.

Food additives are used in dairy products to enhance palatability, diversity and desirability. Some researchers investigated that the effect of some additives such as salt, mint, some essential oils on probiotic microorganisms and found impressive results about the stimulatory or inhibitory effect (Vinderola et al., 2002a; Mohammadi et al., 2012). However, little is known about the survival of probiotic bacteria in yogurt supplemented with garlic which known to have antimicrobial activity.

The aim of the current study was to investigate the viability of probiotic microorganisms Bifidobacterium longum BB536, Lactobacillus acidophilus 74-2, Lactobacillus rhamnosus Howaru HNOO1 ${ }^{\mathrm{TM}}$ in Cacık to provide a functional aspect. The specific objectives of this study were to identify the optimal probiotic bacteria combination that survives at maximum cell number over three weeks of storage, reveal the interaction between these strains and their effect on physicochemical and sensorial properties of products.

\section{Materials and methods}

\section{Starter, probiotic cultures and other \\ ingredient materials}

Freeze dried starter culture (SC) (F-DVS YoFlex Premium 2.0), which contains a mixture of Streptococcus thermophilus (ST) and Lactobacillus delbrueckii spp. bulgaricus (L. bulgaricus) (LB) (Peyma-Chr. Hansen (Istanbul, Turkey) and probiotic cultures Bifidobacterium longum BB536 (BL), Lactobacillus acidophilus 74-2 (LA) and Lactobacillus rhamnosus Howaru HNOO1 ${ }^{\mathrm{TM}}$ (LR) (Danisco-Dupont Copenhagen, Denmark) were inoculated with $1 \%$ in UHT milk (UHT-M) to prepare inoculum. Garlic, spearmint, salt, cucumber and UHT-M were supplied from a local market in Bursa, Turkey.

\section{Production of Cacık}

Standardized and pasteurized $\left(87 \pm 2{ }^{\circ} \mathrm{C}\right.$ for 5 minutes) milk (SP-M) was obtained at $4{ }^{\circ} \mathrm{C}$ from a local dairy factory in Bursa-Karacabey region. Eighteen liters of the milk was distributed into 500 $\mathrm{mL}$ volume as thirty-six separate sterile plastic (polypropylene) cups and inoculated with $3 \%(\mathrm{w} / \mathrm{w})$ of one of the three probiotic culture and $3 \%(\mathrm{w} / \mathrm{w})$ starter cultures. Cups were incubated at $41 \pm 1{ }^{\circ} \mathrm{C}$ to reach the $\mathrm{pH} 4.60 \pm 0.02$ and then immediately cooled down to $15 \pm 2{ }^{\circ} \mathrm{C}$. pH was measured with a pH meter (model 8417; HANNA Instruments, Singapore) (Donkor et al., 2006). Subsequently $0.02 \%$ crushed garlic, $0.02 \%$ dried spearmint, $0.02 \%$ salt and $16.25 \%$ diced cucumber were added to each yogurt to produce Cacık (Figure 1). These ratios of supplements were determined by sensorial analysis results of a preliminary study.

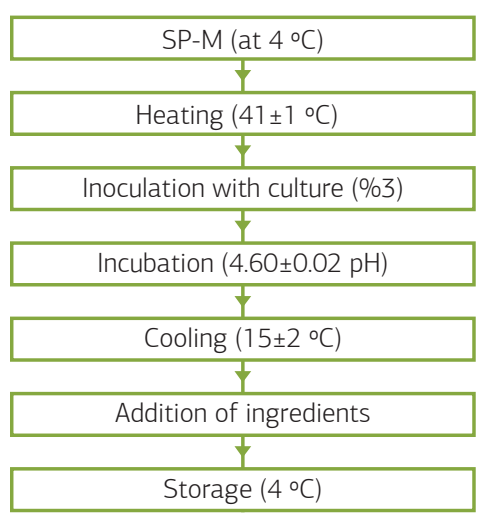

FIGURE 1. Process diagram for the production of Cacık 


\section{Experimental design}

Starter cultures were used as the main culture and seven different Cacık samples with two controls $(C 1, C 2, C 3, C 4, C 5, C 6, C 7, C 8, C 9)$ were obtained with different combinations of probiotic cultures containing all of the afore mentioned ingredients as presented in Table 1. Standardized and pasteurized milk (SP-M) was analysed prior to production for fat, total solids and proteins. $\mathrm{pH}$ analysis was carried out at half an hour intervals during fermentation after the second hour until reaching the value of $4.60 \pm 0.2$. Protein, fat, total solids and consistency of Cacık were determined only at the day after fermentation. In all analysis, C1 was compared with C2 for determining the effect of garlic on yogurt bacteria. For the other groups, the $\mathrm{C} 1$ group was excluded and the other eight groups (C2, C3, C4, C5, C6, C7, C8, C9) were compared with each other.

For the shelf life study, Cacık samples were stored at $4{ }^{\circ} \mathrm{C}$ for 21 days in $500 \mathrm{~mL}$ volume plastic sterile cups. $\mathrm{pH}$ was analysed at one-day intervals, beginning at the day after fermentation to the end of storage. Probiotic and yogurt bacteria were enumerated at the $0,10^{\text {th }}$ and $21^{\text {th }}$ day of storage. Other than sensorial analysis, each test was conducted with three replicates. All data of the experiments were expressed as the mean \pm standard deviation (SD).

\section{Physicochemical analysis}

\section{Protein, fat and total dried matter determination}

The protein and fat of SP-M, UHT-M and Cacık were determined according to reference method of ISO 8968 (2014) by using Kjeltec 2200 and ISO 2446 (2008) (for SP-M and UHT-M), ISO 11870 (2009) (for Cacık), respectively. Total dried matter (TDM) was determined as described reference method of ISO 13580 (2005). Briefly, 3 g of samples were placed into pre-weighed and pre-dried alumina cups. After drying for $2.5 \mathrm{~h}$ (for Cacık) or $4 \mathrm{~h}$ (for SP-M and UHT-M) in an oven at $103 \pm 2{ }^{\circ} \mathrm{C}$, samples were cooled at room temperature in the desiccator. Then, the total solids were calculated.
TABLE 1. Production of Cacik with different cultures and content

\begin{tabular}{|c|c|}
\hline Treatments & Bacterial combinations / content \\
\hline $\mathrm{Cl}$ & $\begin{array}{l}\text { SC / diced cucumber, dried } \\
\text { spearmint, salt without garlic }\end{array}$ \\
\hline $\mathrm{C} 2$ & $\begin{array}{l}\text { SC / diced cucumber, dried } \\
\text { spearmint, salt and garlic }\end{array}$ \\
\hline C3 & $\begin{array}{l}\mathrm{SC}+\mathrm{BL} / \text { diced cucumber, dried } \\
\text { spearmint, salt and garlic }\end{array}$ \\
\hline C4 & $\begin{array}{l}\mathrm{SC}+\mathrm{LA} / \text { diced cucumber, dried } \\
\text { spearmint, salt and garlic }\end{array}$ \\
\hline$C 5$ & $\begin{array}{l}\text { SC + LR / diced cucumber, dried } \\
\text { spearmint, salt and garlic }\end{array}$ \\
\hline C6 & $\begin{array}{l}\mathrm{SC}+\mathrm{BL}+\mathrm{LA} / \text { diced cucumber, } \\
\text { dried spearmint, salt and garlic }\end{array}$ \\
\hline C7 & $\begin{array}{l}\mathrm{SC}+\mathrm{BL}+\mathrm{LR} / \text { diced cucumber, } \\
\text { dried spearmint, salt and garlic }\end{array}$ \\
\hline C8 & $\begin{array}{l}\mathrm{SC}+\mathrm{LA}+\mathrm{LR} / \text { diced cucumber, } \\
\text { dried spearmint, salt and garlic }\end{array}$ \\
\hline C9 & $\begin{array}{l}\mathrm{SC}+\mathrm{BL}+\mathrm{LA}+\mathrm{LR} / \text { diced } \\
\text { cucumber, dried spearmint, } \\
\text { salt and garlic }\end{array}$ \\
\hline
\end{tabular}

SC: Starter culture, BL: Bifidobacterium longum BB536, LA: Lactobacillus acidophilus 74-2, LR: Lactobacillus rhamnosus Howaru HNOO1 ${ }^{\mathrm{TM}}$. All samples includes spearmint and salt at same proportion.

\section{Consistency analysis}

The consistency values of the Cacık were determined by Gerber Instruments Bostwick consistometer described by Vargas et al. (2008).

\section{Selective enumeration of yogurt and probiotic bacteria in Cacık}

The number of viable cells of probiotic and yogurt bacteria in Cacık samples were determined by the pour plate technique. $10 \mathrm{~g}$ of samples were homogenized in $90 \mathrm{~mL}$ of Ringer solution (Merck, Darmstadt, Germany) using a Stomacher 400 (Seward Co., London, United Kingdom) and serially diluted $\left(10^{2}-10^{9}\right)$ with the same diluent. Starter and 
probiotic bacteria enumeration were performed according to displayed at Supplementary Table S1 (Farnsworth et al., 2006; Tharmaraj and Shah 2003). For obtaining anaerobic condition, an anaerobic jar using Anaerogen Gas-packs (Oxoid, Basingstoke England) were used. The counts of each bacterial strain were expressed as the $\log _{10}$ of the colony forming units per gram of Cacık (So dini et al., 2002).

\section{Sensorial analysis}

Sensory attributes of Caclk samples was carried out by 15 semi-trained panelists (60.0 \% female, 40.0 $\%$ male; aged from 23 to 55 years old) according to the methodology described by Ozturk et al. (2017).

\section{Statistical analysis}

All data of the experiments were analyzed using IBM SPSS Statistics 22 for Windows (SPSS Inc., Chicago, USA) at a confidence level of $95 \%$ according to Magalhães et al. (2016) by considering data sets distribution (normality test with Kolmogorov-Smirnov, parametric - ANOVA and Tukey multiple comparison tests, non-parametric - Kruskal Wallis and Mann-Whitney $U$ tests) Storage analysis was evaluated with repeated measures ANOVA (Bonferroni) test. The relationship of protein, fat or total dried matter and Bostwick consistency was evaluated using Pearson correlation analysis. Absolute correlation coefficients are classified according to Evans (1996) as "very weak" (0.00-0.19), "weak" (0.20-0.39), "moderate" (0.40-0.59), "strong" (0.60-0.79), and "very strong" (0.80-1.0). The sensorial evaluation was performed by using Wilcoxon Signed Rank Test.

\section{Results and discussion}

\section{Physicochemical properties}

Physicochemical analyses of SP-M, UHT-M and Cacık products are summarized in Table 2 and Table 3. As compared to Kucukoner et al.'s (2006) results, protein and total dried matter are higher than the present study findings. The consistency of foodstuff especially semi-solid fluids represents their textural properties. Different consistency results cause different sensorial assessments because of varied rates of taste elements from the compounds of food into the mouth. Bostwick flow values of samples were determined between

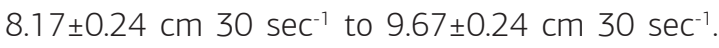
The greater value obtained with Bostwick consistometer indicates less viscous products. Correlation analysis showed that fat or protein content were not correlated ( $r$ : -0.270 and P: $0.174 ;$; $:-0.239$ and P: 0.229), but the total dried matter was correlated with Bostwick consistency as strong negatively ( $r$ : -0.612 and P: 0.001) which infer that the higher levels of the total dried matter lead to lower distance of samples in consistometer. Similar observations were obtained by Vargas et al. (2008) and Isanga and Zhang (2009).

TABLE 2. Composition of SP-M and UHT-M used to prepare yogurt formulations and inoculum

\begin{tabular}{l|l|l|l|l}
\hline Milk & pH & Fat (\%) & Protein (\%) & TDM (\%) \\
\hline SP-M & 6.55 & 3.16 & 3.97 & 14.73 \\
\hline UHT-M & 6.70 & 3.13 & 3.07 & 11.20 \\
\hline
\end{tabular}

TDM: Total dried matter

TABLE 3. Physicochemical properties of Cacık at different bacteria combinations

\begin{tabular}{|c|c|c|c|c|c|}
\hline Samples & Fat (\%) & Protein (\%) & Total dried matter (\%) & Consistency $\left(\mathrm{cm} 30 \mathrm{sec}^{-1}\right)$ & Fermentation time $\left(t_{f}\right)(h)$ \\
\hline $\mathrm{C} 1$ & $2.17 \pm 0.01^{\mathrm{a}}$ & $4.09 \pm 0.01^{c}$ & $14.95 \pm 0.02 b$ & $8.33 \pm 0.24^{\mathrm{e}}$ & $4.33 \pm 0.04^{d}$ \\
\hline $\mathrm{C2}$ & $2.15 \pm 0.01^{\mathrm{ab}}$ & $4.06 \pm 0.01^{d}$ & $14.74 \pm 0.01^{c d}$ & $8.50 \pm 0.00^{\text {def }}$ & $4.00 \pm 0.00^{f}$ \\
\hline C3 & $2.16 \pm 0.00^{b}$ & $4.05 \pm 0.01^{d}$ & $14.72 \pm 0.02^{\mathrm{d}}$ & $8.83 \pm 0.24^{\text {cd }}$ & $4.50 \pm 0.00^{c}$ \\
\hline C4 & $2.13 \pm 0.01^{c}$ & $4.01 \pm 0.01^{\mathrm{e}}$ & $14.63 \pm 0.01^{e}$ & $9.67 \pm 0.24^{a}$ & $4.22 \pm 0.04^{e}$ \\
\hline C5 & $2.12 \pm 0.00^{c d}$ & $4.11 \pm 0.01^{\mathrm{a}}$ & $14.99 \pm 0.01^{\mathrm{a}}$ & $8.83 \pm 0.24^{\text {cd }}$ & $5.25 \pm 0.00^{\mathrm{a}}$ \\
\hline C6 & $2.11 \pm 0.01^{\text {de }}$ & $4.09 \pm 0.01^{b}$ & $14.58 \pm 0.02^{f}$ & $9.50 \pm 0.00^{\mathrm{a}}$ & $5.00 \pm 0.00^{b}$ \\
\hline C7 & $2.10 \pm 0.00^{e}$ & $4.09 \pm 0.01^{b}$ & $14.75 \pm 0.02^{c}$ & $9.00 \pm 0.00^{\mathrm{bc}}$ & $5.22 \pm 0.04^{a}$ \\
\hline C8 & $2.13 \pm 0.01^{c}$ & $4.10 \pm 0.01^{\mathrm{ab}}$ & $14.77 \pm 0.01^{c}$ & $8.17 \pm 0.24^{f}$ & $5.00 \pm 0.00^{b}$ \\
\hline C9 & $2.17 \pm 0.01^{b}$ & $4.12 \pm 0.01^{\mathrm{a}}$ & $14.48 \pm 0.01^{g}$ & $9.33 \pm 0.24^{\mathrm{ab}}$ & $3.81 \pm 0.04 \mathrm{~g}$ \\
\hline
\end{tabular}

C1: SC / without garlic, C2: SC / with garlic (control), C3: SC + BL / with garlic, C4: SC + LA / with garlic, C5: SC + LR / with garlic, C6: SC + BL + LA / with garlic, C7: SC + BL + LR / with garlic, C8: SC + LA + LR / with garlic, C9: SC + BL + LA + LR / with garlic. SC: Starter culture, BL: Bifidobacterium longum BB536, LA: Lactobacillus acidophilus 74-2, LR: Lactobacillus rhamnosus Howaru HNO01 ${ }^{\mathrm{TM}}$. Different small letter superscripts indicate the statistical difference within a column among the samples. 
The $\mathrm{pH}$ values of the samples are shown in Figure 2. The samples fermented with starter cultures only (Figure 2a) were aimed to determine the effect of garlic on the production of acid of $L$. delbreuckii spp. bulgaricus and S. thermophilus. In the second hour of incubation, $\mathrm{pH}$ values of samples without garlic and control samples were $5.19 \pm 0.02$ and 5.36 \pm 0.00 , respectively $(P<0.05)$. But, the control was the group with the fastest decrease in $\mathrm{pH}$ observed during the incubation period and the fermentation time $\left(\mathrm{t}_{\mathrm{f}}\right)$ was determined as $4.0 \mathrm{~h}$ before nearly half an hour of $C 1$ samples $(P<0.05)$. The presence of garlic did not affect adversely $\mathrm{pH}$ development or bacterial growth.

Products containing the combination of probiotic bacteria with starter cultures, excluding $L$. rhamnosus Howaru HNOO1 ${ }^{\mathrm{TM}}$ and three probiotic combination groups, the incubation time retarded prominently. Several studies showed that the fermentation time of yogurt could vary depending on the probiotic strain, even adjunction of probiotics could prolong the incubation period (Yilmaz-Ersan and Kurdal, 2014; Saccaro et al., 2009). Figure $2 b$ shows the samples with incorporated single probiotic with starters and control sample. The $\mathrm{pH}$ values of $\mathrm{C} 3, \mathrm{C} 4$ and $\mathrm{C} 5$ samples decreased to $4.60 \pm 0.02$ after $4.5,4.2$ and 5.2 hours, respectively $(P<0.05)$. These results showed that the presence of $L$. acidophilus 74-2 had more effect on $\mathrm{pH}$ development than other probiotic bacteria. However, the control sample reached the end of fermentation significantly earlier than C4. This could be explained by the interaction between $L$. acidophilus 74-2 and starter culture. Mani-López et al. (2014) reported that the fermentation period in the group containing starter cultures and L. acidophilus was shorter than that in the control group only starter culture. In contrast, prolongation of fermentation time stemmed from an excessive L. acidophilus inoculation, which was demonstrated by OIson and Aryana (2008). Among the samples containing two probiotics, the longest fermentation time $\left(\mathrm{t}_{\mathrm{f}}=\right.$ $5.25 \mathrm{~h}$ ) was observed in the mixtures $\mathrm{L}$. rhamnosus Howaru HNOO1 ${ }^{\mathrm{TM}}$ and B. longum BB536 with starters. This supports the notion that the presence of $L$. acidophilus 74-2 has an effect on the development of acidity, such as the results obtained in groups
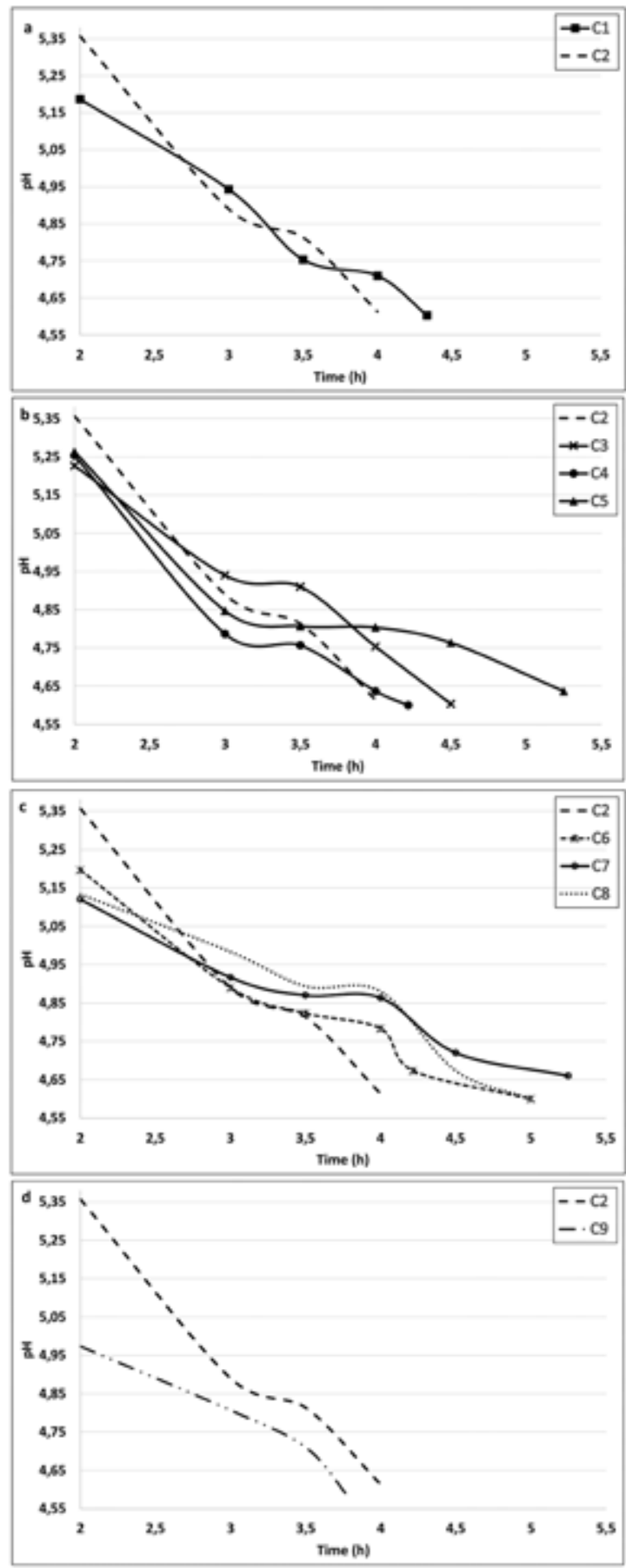

FIGURE 2. Changes in pH during fermentation of samples. C1: SC / without garlic, C2: SC / with garlic (control), C3: SC + BL / with garlic, C4: SC + LA / with garlic, C5: SC + LR/ with garlic, C6: $\mathrm{SC}+\mathrm{BL}+\mathrm{LA} /$ with garlic, $\mathrm{C7}: \mathrm{SC}+\mathrm{BL}+\mathrm{LR} /$ with garlic, $C$ 8: $S C+L A+L R /$ with garlic, C9: $S C+B L+L A+L R /$ with garlic. SC: Starter culture, BL: Bifidobacterium longum BB536, LA: Lactobacillus acidophilus 74-2, LR: Lactobacillus rhamnosus Howaru HNOO1 ${ }^{\mathrm{TM}}$. 
containing single probiotic combinations. The samples of C 6 and $\mathrm{C} 8$ reached the designated $\mathrm{pH}$ value at the same time statistically. The samples inoculated with three probiotics required the shortest fermentation time $\left(t_{f}=3.8 \mathrm{~h}\right)$ when compared with all groups.

Four different forms of interaction between starter and probiotic bacteria have been described as stimulating each other, delay growth, complete inhibition of growth, or have no effect among them (Vinderola et al. 2002b). It is thought that the differences in $\mathrm{pH}$ development during incubation have been directly related to all these interactions.

\section{Storage analysis}

\section{Post-acidification}

The metabolic activities of microorganisms during the storage cause decrease in $\mathrm{pH}$ with regard to the accumulation of organic acids (Settachaimongkon et al., 2014). This phenomenon is defined as "post-acidification" and is decisive not only for the survival of probiotic and starter microorganisms, but also for the consumer's preferences.

The $\mathrm{pH}$ decreased gradually in all treatments over 21 days of storage (Table 4). The addition of garlic affected the acid production adversely at first and 10th days but the end of the storage it was determined that there were no significant differences in the $\mathrm{pH}$ value between the control groups. Contrary to this, the fermentation profile of these samples was not compatible with post-acidification results.

Zacarchenco and Massaguer-Roig (2006) reported that Bifidobacterium spp. produces acetic acids and lactic acids at the ratio 3:2 during incubation. The presence of acetic acid has a detrimental effect on starter cultures. Therefore, the viable cells of L. delbreuckii spp. bulgaricus, which is mainly responsible for post acidification process, reduces as the amount of acetic acid increases. However, in co-culture with B. longum BB536 at the current study, acidification process throughout the refrigerated storage was similar to control samples even if L. delbreuckii spp. bulgaricus cell counts decreased. The possible explanation to the discrepancy between literature and current results is the specificity of the response of the different strains to the experimental conditions, interaction with other species, inoculum size. The $\mathrm{pH}$ values of the yogurt inoculated with B. longum BB536 and L. acidophilus 74-2 were significantly higher than other samples at the end of the storage. Maximum pH reduction was observed in which association with standard yogurt cultures (L. delbreukii spp. bulgaricus and S. thermophilus) and three probiotics. A similar finding was obtained in the fermentation profile of samples in the present study.

\section{Bacterial interactions and survival of probiotic strains and starter cultures}

Factors such as organic acid concentration, $\mathrm{pH}$ value, presence of hydrogen peroxide, amounts of dissolved oxygen, storage temperature, food matrix, level of free amino acids, peptides compounds in food, superoxide anions and hydroxyl radicals play key role on the viability of probiotic microorganisms in fermented dairy products (Rutella et al. 2016; Klu et al., 2012; Shah, 2007).

Use of starter cultures (S. thermophilus and $L$. delbreukii spp. bulgaricus) with probiotics in a commercial product is preferred because of the poor fermentation ability of probiotic microorganisms. In our pre-study, the fermentation time $\left(\mathrm{t}_{\mathrm{f}}\right)$ of co-culture with three probiotics was nearly sixteen hours. Besides they cause the development of undesirable taste and odour when used alone (Champagne et al. 2009; Mahmoudi et al., 2013). However, the interaction between microorganisms is the most important criterion for the selection of probiotic strain. Although the relationship of starter bacteria is known in detail, very few studies revealed the behavior of the coexistence between starter and probiotic culture.

As displayed in Table 4, viable cell counts of S. thermophilus increased or decreased depending on the type of inoculum over 21 days of storage. On the first day, the counts of $\mathrm{S}$. thermophilus were not statistically different among different samples, but thereafter there was a significant difference depending on the bacterial strain combination. Neither S. thermophilus nor $L$. bulgaricus cells were affected by supplementation of garlic through the storage. These findings were in agreement with previous studies which indicated that lactic acid bacteria $(L A B)$ is not inhibited by garlic (Altuntas and Korukluoglu, 2019; Shalini et al. 2017; Michael et al., 2015; Zhang et al., 2013). 
TABLE 4. Changes in $\mathrm{pH}, \log _{10}\left(\mathrm{CFU} \mathrm{g}^{-1}\right)$ viable cells of starters and probiotics in Cacık samples with different bacteria combinations over 21 days of storage

\begin{tabular}{|c|c|c|c|c|c|c|c|}
\hline & Time (days) & $\mathrm{pH}$ & S. thermophilus & L. bulgaricus & L. acidophilus & L. rhamnosus & B. longum \\
\hline \multirow{4}{*}{ C1 } & 1 & $4.50 \pm 0.02^{\mathrm{Ad}}$ & $8.89 \pm 0.01^{\mathrm{Ab}}$ & $8.31 \pm 0.04^{\mathrm{Ab}}$ & & & \\
\hline & 10 & $4.10 \pm 0.00^{\mathrm{Bd}}$ & $8.58 \pm 0.06^{\mathrm{Ae}}$ & $8.25 \pm 0.04^{\mathrm{Bd}}$ & & & \\
\hline & 21 & $4.00 \pm 0.02^{\mathrm{Be}}$ & $8.46 \pm 0.06^{\mathrm{Bd}}$ & $8.14 \pm 0.10^{\mathrm{Bd}}$ & & & \\
\hline & Tot. var. & $-0.50 \pm 0.00$ & $-0.43 \pm 0.03$ & $-0.16 \pm 0.07$ & & & \\
\hline \multirow{4}{*}{ C2 } & 1 & $4.57 \pm 0.01^{\text {Aab }}$ & $8.70 \pm 0.06^{\mathrm{Aab}}$ & $8.21 \pm 0.07^{\mathrm{Aab}}$ & & & \\
\hline & 10 & $4.18 \pm 0.01^{\mathrm{Bab}}$ & $8.69 \pm 0.02^{\text {Ade }}$ & $8.19 \pm 0.08^{\text {Acd }}$ & & & \\
\hline & 21 & $4.01 \pm 0.01 C^{\text {cde }}$ & $8.59 \pm 0.04^{\mathrm{Acd}}$ & $8.29 \pm 0.05^{\mathrm{Abd}}$ & & & \\
\hline & Tot. var. & $-0.56 \pm 0.00$ & $-0.11 \pm 0.05$ & $0.08 \pm 0.06$ & & & \\
\hline \multirow{4}{*}{$\mathrm{C} 3$} & 1 & $4.54 \pm 0.01^{\mathrm{Abc}}$ & $8.88 \pm 0.08^{\mathrm{Aa}}$ & $8.31 \pm 0.04^{\mathrm{Aa}}$ & & & $7.37 \pm 0.05^{\mathrm{AL}}$ \\
\hline & 10 & $4.11 \pm 0.01^{\text {Bcef }}$ & $8.85 \pm 0.03^{A C}$ & $8.19 \pm 0.05^{\mathrm{ABC}}$ & & & $6.52 \pm 0.03^{B}$ \\
\hline & 21 & $4.03 \pm 0.01^{\mathrm{cbc}}$ & $8.55 \pm 0.03^{B C}$ & $8.07 \pm 0.03^{\mathrm{BC}}$ & & & $4.93 \pm 0.07^{c}$ \\
\hline & Tot. var. & $-0.51 \pm 0.00$ & $-0.34 \pm 0.05$ & $-0.25 \pm 0.03$ & & & $-2.45 \pm 0.06$ \\
\hline \multirow{4}{*}{ C4 } & 1 & $4.52 \pm 0.01^{\mathrm{Ac}}$ & $8.76 \pm 0.02^{\mathrm{Aa}}$ & $8.32 \pm 0.04^{\mathrm{Ba}}$ & $7.92 \pm 0.05^{\mathrm{Ab}}$ & & \\
\hline & 10 & $4.08 \pm 0.01^{\text {Bef }}$ & $8.67 \pm 0.03^{\mathrm{Ad}}$ & $8.19 \pm 0.01^{\mathrm{BC}}$ & $7.50 \pm 0.04^{\mathrm{BC}}$ & & \\
\hline & 21 & $4.00 \pm 0.01^{c c d}$ & $8.64 \pm 0.04^{\mathrm{BC}}$ & $8.42 \pm 0.06^{\mathrm{Aab}}$ & $7.23 \pm 0.04^{\mathrm{cd}}$ & & \\
\hline & Tot. var. & $-0.52 \pm 0.00$ & $-0.12 \pm 0.03$ & $0.10 \pm 0.05$ & $-0.69 \pm 0.05$ & & \\
\hline \multirow{4}{*}{ C5 } & 1 & $4.56 \pm 0.00^{\mathrm{Aabc}}$ & $8.81 \pm 0.02^{\mathrm{Aa}}$ & $8.34 \pm 0.04^{\mathrm{Aa}}$ & & $8.22 \pm 0.06^{\mathrm{Aa}}$ & \\
\hline & 10 & $4.07 \pm 0.02^{\text {Bef }}$ & $8.95 \pm 0.01^{\mathrm{Abc}}$ & $8.36 \pm 0.06^{\mathrm{Abc}}$ & & $8.36 \pm 0.05^{A b}$ & \\
\hline & 21 & $4.06 \pm 0.01^{\mathrm{Bb}}$ & $8.96 \pm 0.01 \mathrm{~A}^{\mathrm{ab}}$ & $8.27 \pm 0.03^{\mathrm{Abc}}$ & & $8.22 \pm 0.07^{\mathrm{Aa}}$ & \\
\hline & Tot. var. & $-0.50 \pm 0.01$ & $0.15 \pm 0.02$ & $-0.07 \pm 0.04$ & & $0.00 \pm 0.07$ & \\
\hline \multirow{4}{*}{ C6 } & 1 & $4.59 \pm 0.01^{\mathrm{Aa}}$ & $8.82 \pm 0.05^{\mathrm{Aa}}$ & $7.79 \pm 0.04^{\mathrm{Aa}}$ & $7.74 \pm 0.10^{\mathrm{Ab}}$ & & $6.97 \pm 0.02^{A c}$ \\
\hline & 10 & $4.21 \pm 0.02^{\mathrm{Bab}}$ & $8.87 \pm 0.02^{A c}$ & $7.77 \pm 0.01^{\mathrm{Ae}}$ & $7.67 \pm 0.14^{\mathrm{ABC}}$ & & $6.83 \pm 0.13^{\mathrm{Ab}}$ \\
\hline & 21 & $4.18 \pm 0.02^{\mathrm{Ba}}$ & $8.86 \pm 0.02^{\mathrm{Ab}}$ & $7.78 \pm 0.05^{\mathrm{Ae}}$ & $7.60 \pm 0.09^{B c}$ & & $5.01 \pm 0.02^{\mathrm{BC}}$ \\
\hline & Tot. var. & $-0.41 \pm 0.01$ & $0.05 \pm 0.04$ & $-0.01 \pm 0.05$ & $-0.14 \pm 0.09$ & & $-1.95 \pm 0.02$ \\
\hline \multirow{4}{*}{ C7 } & 1 & $4.52 \pm 0.01^{A c}$ & $8.88 \pm 0.07^{\mathrm{Aa}}$ & $8.34 \pm 0.07^{\mathrm{Aa}}$ & & $8.37 \pm 0.07^{\mathrm{Aa}}$ & $8.18 \pm 0.10^{\mathrm{Aa}}$ \\
\hline & 10 & $4.15 \pm 0.00^{\mathrm{Bbc}}$ & $9.05 \pm 0.05^{\text {Bab }}$ & $8.37 \pm 0.02^{\mathrm{Abc}}$ & & $8.44 \pm 0.06^{\mathrm{Aab}}$ & $8.41 \pm 0.05^{\text {Aa }}$ \\
\hline & 21 & $4.01 \pm 0.01^{\mathrm{cc}}$ & $8.96 \pm 0.02^{\mathrm{Bab}}$ & $8.34 \pm 0.04^{\mathrm{Ab}}$ & & $8.28 \pm 0.04^{\mathrm{Aa}}$ & $8.27 \pm 0.07^{\mathrm{Aa}}$ \\
\hline & Tot. var. & $-0.51 \pm 0.00$ & $0.08 \pm 0.04$ & $-0.05 \pm 0.05$ & & $-0.09 \pm 0.06$ & $0.08 \pm 0.09$ \\
\hline \multirow[t]{4}{*}{$\mathrm{C} 8$} & 1 & $4.55 \pm 0.01^{\text {Aabc }}$ & $8.86 \pm 0.06^{\mathrm{Aa}}$ & $8.31 \pm 0.04^{\mathrm{Ba}}$ & $8.39 \pm 0.05^{\mathrm{Aa}}$ & $8.15 \pm 0.09^{\mathrm{ca}}$ & \\
\hline & 10 & $4.08 \pm 0.01^{\text {Bef }}$ & $9.09 \pm 0.04^{\mathrm{ABa}}$ & $8.54 \pm 0.04^{\mathrm{Aa}}$ & $8.61 \pm 0.02^{\mathrm{Aa}}$ & $8.61 \pm 0.03^{\mathrm{Aa}}$ & \\
\hline & 21 & $3.97 \pm 0.01^{\mathrm{Cd}}$ & $9.04 \pm 0.03^{\mathrm{Ba}}$ & $8.22 \pm 0.11^{\mathrm{Bbc}}$ & $8.33 \pm 0.07^{\mathrm{Aa}}$ & $8.34 \pm 0.04^{\mathrm{Ba}}$ & \\
\hline & Tot. var. & $-0.58 \pm 0.00$ & $0.18 \pm 0.05$ & $-0.10 \pm 0.08$ & $-0.06 \pm 0.07$ & $0.19 \pm 0.07$ & \\
\hline \multirow[t]{4}{*}{ C9 } & 1 & $4.47 \pm 0.01^{\mathrm{Ae}}$ & $8.73 \pm 0.04^{\mathrm{Aa}}$ & $8.61 \pm 0.0^{1 \mathrm{Aa}}$ & $8.53 \pm 0.04^{\mathrm{Aa}}$ & $8.15 \pm 0.10^{\mathrm{Aa}}$ & $8.12 \pm 0.04^{\mathrm{Aa}}$ \\
\hline & 10 & $4.07 \pm 0.01^{\mathrm{Bf}}$ & $8.67 \pm 0.03^{\mathrm{Ad}}$ & $8.56 \pm 0.03^{\mathrm{Aab}}$ & $8.23 \pm 0.08^{\mathrm{ABD}}$ & $8.16 \pm 0.08^{A C}$ & $8.21 \pm 0.12^{\mathrm{Aa}}$ \\
\hline & 21 & $3.90 \pm 0.00^{\mathrm{cf}}$ & $8.64 \pm 0.03^{A C}$ & $8.58 \pm 0.04^{\mathrm{Aa}}$ & $7.97 \pm 0.03^{\mathrm{Bb}}$ & $7.96 \pm 0.01^{\mathrm{Ab}}$ & $7.51 \pm 0.01^{\mathrm{Bb}}$ \\
\hline & Tot. var. & $-0.57 \pm 0.01$ & $-0.08 \pm 0.04$ & $-0.03 \pm 0.03$ & $-0.56 \pm 0.03$ & $-0.19 \pm 0.06$ & $-0.61 \pm 0.03$ \\
\hline
\end{tabular}

Tot. var.: Total variation. C1: SC / without garlic, C2: SC / with garlic (control), C3: SC + BL / with garlic, C4: SC + LA / with garlic, C5: SC + LR / with garlic, C6: SC + BL + LA / with garlic, C7: SC + BL + LR / with garlic, C8: SC + LA + LR / with garlic, C9: SC + BL +LA + LR / with garlic. SC: Starter culture, BL: Bifidobacterium longum BB536, LA: Lactobacillus acidophilus 74-2, LR: Lactobacillus rhamnosus Howaru $\mathrm{HNOO1}^{\mathrm{TM}}$. Total variation was calculated by the last day result minus the first day result. Results presented as a mean $(n=3) \pm$ standard deviation. Different small letter superscripts indicate the statistical difference within a column among the samples, $\mathrm{P}<0.05$. Different capital letter superscripts indicate the statistical difference within a column in themselves $P<0.05$. 
Results showed that the presence of $L$. acidophilus 74-2 did not affect the population of $\mathrm{S}$. thermophilus. Nevertheless, Dave (1998) reported that the inhibitory effect of L. acidophilus on S. thermophilus was strain dependent. On the $10^{\text {th }}$ day of refrigerated storage, the higher viable counts of $S$. thermophilus in co-culture with B. longum BB536 samples than in the control sample might be explained by a stimulatory effect of B. longum BB536 alone. Similar observations were established in studies of Chekroun et al. (2006) and Wang et al. (2005). They confirmed that bifidobacteria could grow better when combined with streptocci and lactobacilli because of the acidifying and proteolysis activity, respectively. However, over time there was a drastic reduction in the population of B. longum BB536 (about $2.45 \mathrm{log}$ ), which resulted in similar the counts of $\mathrm{S}$. thermophilus like in the control sample. The same stimulation effect on $\mathrm{S}$. thermophilus was observed with the counts L. rhamnosus Howaru HNOO1 ${ }^{\mathrm{TM}}$ which remained constant over 21 days of storage. In co-culture with all two probiotic content, the population of S. thermophilus was significantly higher than in the control sample. There was no decrease in S. thermophilus counts until the end of storage in these groups. Although, it has been determined that the presence of one or two probiotic bacteria supported the growth of S. thermophilus, while the triple probiotic bacterial combination did not have the same effect. This unexpected finding indicated that the interaction between bacteria could be affected by different mechanisms of tested bacteria or lack of certain nutrition or the accumulation of metabolites. Similarly, Kos et al. (2011) and Leboš Pavunc et al. (2013) emphasized that the antimicrobial activity of the adjacent cultures can result in inhibiting desirable autochthonous population. However, they reported that the effect is desirable when the antimicrobial spectrum of adjacent cultures includes spoilage, contaminant strains.

Several researchers suggested that the low number of $L$. bulgaricus positively affects the viability of probiotic bacteria, otherwise, the regressive $\mathrm{pH}$ level of the product during storage arising from L. bulgaricus injured pH-sensitive strains (Dave, 1998; Lourens-Hattingh and Viljoen, 2001). In all samples, on the first day of storage, the population of $L$. bulgaricus was not statistically significant.
Out of the three bacterial combinations that contained L. rhamnosus Howaru HNOO1 ${ }^{\mathrm{TM}}$ or L. acidophilus 74-2 or B. longum BB536, only adjunction of B. longum BB536 had an adverse effect on survival of $L$. bulgaricus. As mentioned above, the acetic acid content produced by B. longum BB536 had a detrimental effect on L. bulgaricus viability (Mohammadi et al., 2012). However, when L. rhamnosus Howaru HNOO1 ${ }^{\mathrm{TM}}$ was added to B. longum BB536, the inhibitory effect of acetic acid on $L$. bulgaricus was minimized. During the trial, it was determined that the addition of $L$. acidophilus 74-2 or L. rhamnosus Howaru HNOO1 ${ }^{\mathrm{TM}}$ alone had no effect on the growth of $L$. bulgaricus. In contrast, a previous study indicated that seven of the eight isolates of L. acidophilus were found to produce antimicrobial compounds that negatively affected the growth of $L$. bulgaricus. These compounds were active at neutral $\mathrm{pH}$ values and sensitive to proteolytic enzymes such as chymotrypsin and papain (Dave, 1998). The fact that the results obtained in the study were different indicated that resulted from acidic $\mathrm{pH}$ values of samples and thus inactivated form of antimicrobial compounds. Viable counts of L. bulgaricus in samples containing co-culture with L. acidophilus 74-2 and B. longum BB536 were lower than in all other combined samples. The highest cell counts of $L$. bulgaricus were recorded throughout the entire refrigerated storage and was directly related to the group at the lowest $\mathrm{pH}$ value among the samples. Excessive $\mathrm{pH}$ decrease of products may give unpleasant sensorial attributes and influence to consumer negatively. As new approaches, the commercial cultures such as ABT (a mixed culture which contains S. thermophilus, L. acidophilus and Bifidobacterium spp.) containing bacteria with proteolytic activity less than that of $L$. bulgaricus are preferred (Kailasapathy et al., 2008).

L. acidophilus is one of the most commonly used probiotic bacteria in dairy products due to its functional properties such as immunomodulatory, antagonistic effect against pathogens, lowering the cholesterol level (Li et al., 2012). Ng et al. (2011) reported that $L$. acidophilus was hampered in the presence of starter culture and when yogurt inoculated with $L$. bulgaricus alone, the hydrogen peroxide level which is the inhibitory effect on L. acidophilus growth is seven to nine-fold higher than those prepared with S. thermophilus together. Also, Donkor 
et al. (2006) stated that the decrease in the number of $L$. acidophilus in yogurt products is related to the accumulation of lactic acid and acetic acid. The poor viability of L. acidophilus mainly due to low $\mathrm{pH}$ level was confirmed by several studies (Hekmat et al., 2009; Shah, 2007). In our study, L. acidophilus 74-2 decreased in all treatments excluding inoculated with L. rhamnosus Howaru HNOO1 ${ }^{\mathrm{TM}}$ during storage. There was no difference in the counts of L. acidophilus 74-2 in C4 and C6 samples showed that B. longum BB536 has no effect on the growth of $L$. acidophilus 74-2. But, in association with $L$. rhamnosus Howaru HNOO1 ${ }^{\mathrm{TM}}$, the growth of $\mathrm{L}$. acidophilus 74-2 enhanced, while the population of cells decreased in other samples.

At the beginning of the storage, there was no statistical difference in the number of $L$. rhamnosus Howaru HNOO1 ${ }^{\mathrm{TM}}$ among the samples. In all four combinations (C5, C7, C8, C9), L. rhamnosus Howaru HNOO1 ${ }^{\mathrm{TM}}$ was found more resistant to the environment than other probiotic bacteria. Hekmat et al., (2009) and Ferdousi et al. (2013) emphasized that $L$. rhamnosus may be preferred as a probiotic microorganism in yogurt products due to good viability. Similarly, in a study of the survivability of probiotic microorganisms in cheese-based dip prepared with different combinations of probiotic bacteria, L. rhamnosus was not significantly affected by any of the tested probiotic bacteria (Tharmaraj and Shah, 2004). In contrast, L. rhamnosus GG growth in milk was low due to the lack of ability to ferment lactose characteristically (Settachaimongkon et al., 2014; Ahlroos and Tynkkynen, 2009). The population of $L$. rhamnosus Howaru $\mathrm{HNOO}^{\mathrm{TM}}{ }^{\mathrm{M}}$ remained at similar levels in either alone or coexistence with B. longum BB536 in the present study. It appears that stimulatory or antagonistic effect of B. longum BB536 on L. rhamnosus Howaru $\mathrm{HNOO}^{\mathrm{TM}}$ was not detected. Over 21 days of storage, the highest population level of $L$. rhamnosus Howaru $\mathrm{HNOO}^{\mathrm{TM}}{ }^{\mathrm{M}}$ was obtained in co-culture with L. acidophilus 74-2. That interaction is named mutualism due to the similar pattern observed for $L$. acidophilus 74-2. These results are coherent with a study of Tharmaraj and Shah (2004). However, the presence of B. longum BB536 and L. acidophilus 74-2 together caused a significant reduction of viable cells of L. rhamnosus Howaru HNOO1 ${ }^{\mathrm{TM}}$.
Extracellular proteinase syntheses of $L A B$ is important for good survival in milk since the free amino acids and peptides levels in milk are very low. Researchers reported that bifidobacteria grow poorly in dairy products due to some disadvantages which were mentioned above. Even though tolerance of accumulation of organic acid varies according to strain-specific, bifidobacteria are more sensitive to acid than other probiotics (Mohammadi et al., 2012). The optimum pH for the growth of Bifidobacterium is 6.0-7.0 and cannot grow below the pH 4.5 (Shah, 2007). Besides, bifidobacteria are anaerobic microorganisms, so the presence of the oxygen exhibit antagonistic effect. As expected in our study, B. longum BB536 showed a lower viable count at the end of storage in alone and in co-culture with $L$. acidophilus 74-2. These results indicated that B. longum BB536 did not compete well with yogurt culture and L. acidophilus $74-2$ or did not overcome stress condition. The viability of selected probiotic strain (more than $10^{6}-10^{7} \mathrm{CFU} \mathrm{g}^{-1}$ ) until the time of consumption has the highest priority to be able to exhibit specific health claims. Therefore, trials of C3 and C6 considered unsuccessful bacterial combination since the viable cell counts dropped below the critical level. In these samples, B. longum BB536 lost 28-33\% of its viability after three weeks of storage. Since the in vitro simulated digestion models permit a good decision about the viability of bifidobacteria, further analysis should be considered before final judgment. The antagonism is defined previously by Dave (1998) who revealed that seven of eight $L$. acidophilus isolates has an inhibitory effect on the growth of B. longum. On the contrary, L. rhamnosus Howaru HNOO1 ${ }^{\mathrm{TM}}$ stimulated the growth of B. longum BB536 significantly. Interestingly, samples containing three probiotic bacteria showed a higher logarithmic reduction than in co-culture with L. rhamnosus Howaru $\mathrm{HNOO}^{\mathrm{TM}}$ at the end of storage. This observation is explained by the inhibitory effect of L. acidophilus 74-2 was dominated even if the presence of $L$. rhamnosus Howaru HNOO1 ${ }^{\mathrm{TM}}$ in the product.

Commercial products which are combined with multiple strains have been proposed as particularly effective for health because of the higher total concentration of bacteria compared to monostrain products (Laterza et al. 2018). However, the production of products containing multiple probiotic 
strains should also be considered in terms of economic aspects. In this study, the product containing the three probiotics has the shortest duration of fermentation and the number of probiotic and yogurt strains during storage up to 7 log. Inevitably, the use of three different commercial probiotics will bring additional burdens on producers.

\section{Sensory profile}

The use of different species, even sub-strain of probiotic bacteria, provides different sensorial attributes to the product. Despite extensive knowledge about the importance of their health claims, consumers do not prefer the product that leaves an unpleasant taste in the mouth. Therefore, the sensory acceptability of the novel probiotic food should be evaluated.

Sensory properties of samples on the basis of flavour, texture overall scores were given in Figure 3. In accordance with Karl Ruther nine points scheme, the acceptable score range should be 4-9
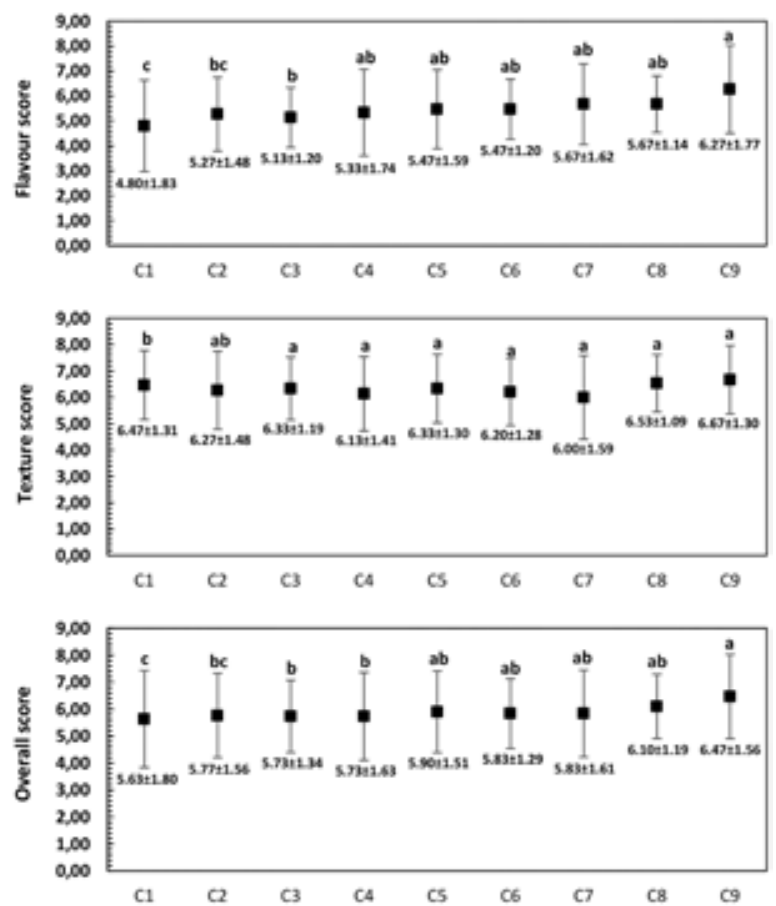

FIGURE 3. Sensory evaluation of Cacık with inoculated different bacteria combination. C1: SC / without garlic, C2: SC / with garlic (control), C3: SC + BL / with garlic, C4: SC + LA / with garlic, C5: SC + LR / with garlic, C6: $\mathrm{SC}+\mathrm{BL}+\mathrm{LA} /$ with garlic, C7: $S C+B L+L R /$ with garlic, C8: $S C+L A+L R /$ with garlic, C9: $S C+B L+L A+L R /$ with garlic. SC: Starter culture, BL: Bifidobacterium longum BB536, LA: Lactobacillus acidophilus 74-2, LR: Lactobacillus rhamnosus Howaru HNOO1 ${ }^{\mathrm{TM}}$ points for commercial yogurt product (Isanga and Zhang, 2009). All mean scores of different bacterial combinations place this interval. Overall score demonstrates the total perception of flavour and texture attributes taken together. Flavour and overall scores of in samples with three were significantly higher than control which means the coherence of three probiotic bacteria with starter culture contributed to sensory properties positively. Indeed, $53.3 \%$, which is the highest acceptability percentage of the consumers gave 7 or higher points to C9 samples (data not shown).

High acetic acid concentration produced by bifidobacteria causes to undesirable vinegar taste. In technical data sheet from supplier stated that B. longum BB536 produces slow acidity and lactic acid in $L(+)$ form and acetic acid. In the current study, the presence of only B. longum BB536 had significantly lower flavour and overall scores than the most satisfactory samples (C9). However, the association of B. longum BB536 with starter cultures has not affected the development of taste in the negative. Nevertheless, B. longum BB536 was scored as only $26.7 \%$ in point of "like slightly" and over by panelists (data not shown).

According to Champagne et al. (2005), probiotic cultures do not tend to change the sensory properties of products. This remark confirms our results which were not significant differences between the supplemented probiotic (single or double) and control, excluding only three probiotic inoculated samples. Similar results were obtained by Turgut and Cakmakci (2018).

\section{Conclusion}

The current study showed that the Cacık has the potential for use as a good probiotic carrier even if it contains a certain amount of garlic. However, the selection of probiotic bacteria is decisive in maintaining the high viability of bacteria throughout the shelf life. This study contributes to our understanding of the interactions between probiotic and starter bacteria which are challenging issue at present. The supplementation by B. longum BB536 or L. rhamnosus Howaru HNO01TM alone stimulated the growth of S. thermophilus, but L. acidophilus 74-2 had no effect on the growth of S. thermophilus. 
While L. acidophilus 74-2 or L. rhamnosus Howaru HN001TM alone did not alter the counts of L. bulgaricus over three weeks, the growth of L. bulgaricus was positively affected in the coexistence of both of them. Results demonstrated that the interaction between L. rhamnosus Howaru HN001TM and L. acidophilus 74-2 could be defined as supportive. Probiotic products containing only B. longum BB536 or B. longum BB536 with L. acidophilus 74-2 did not accomplish in terms of the technological point. Further investigations for enhancing the viability of B. longum BB536 in these combination are needed. It is noteworthy that the correct probiotic strain selection makes the maintenance of the sufficient number of the viable bacterial cells possible. Based on the sensory evaluation and considering the technological aspect, Cacık supplemented with L. rhamnosus Howaru HN001TM alone or B. long- um BB536 and L. rhamnosus Howaru HN001TM or L. acidophilus 74-2 and L. rhamnosus Howaru HN001TM or the three probiotic cultured can be produced by the manufacturer who eager to produce novel fermented dairy products containing probiotics.

\section{Acknowledgments}

This study is a part of MSc thesis of the corresponding author at Uludağ University of Food Engineering Department. We would like to thank the Uludağ University for providing necessary resources to carry out our research. This research did not receive any specific grant from funding agencies in the public, commercial, or not-for-profit sectors.

\section{Utjecaj različitih komercijalnih probiotičkih kultura sa starterima na tehnološka, fizikalno-kemijska i senzorska svojstva tradicionalnog jogurtnog predjela Cacık}

\section{Sažetak}

Izbor odgovarajuće probiotičke kulture neophodan je za održavanje adekvatnog broja živih stanica do potrošnje, budući da postoji potencijalno nepovoljna interakcija između odabranog soja i starter kulture. Ova studija ispitala je prikladnost Cacıka kao potencijalnog nositelja probiotika, uključujući Lactobacillus acidophilus 74-2, Lactobacillus rhamnosus Howaru HNO01 ${ }^{\mathrm{TM}}$ i Bifidobacterium longum BB536 u različitim kombinacijama. Prisutnost tri probiotika uzrokovala je višu postacidifikaciju i kraće vrijeme fermentacije povezano s većim brojem stanica soja L. bulgaricus. Osim određenih kombinacija koje sadrže B. longum BB536, broj pojedinačnih probiotičkih bakterija bio je veći od $6 \log ^{-1}{ }^{-1}$ za sve uzorke Cacık s dodatkom probiotika. Rezultati su pokazali da je bakterijska interakcija bila presudna za preživljavanje tijekom 21 dana skladištenja. U uzorcima koji su sadržavali soj B. longum BB536 sam ili u kombinaciji sa sojem L. acidophilus 74-2 zabilježen je pad broja živih stanica za 2,45 log i 1,95 log po g, zbog čega su se ove kombinacije pokazale neuspješnima u smislu kreiranja probiotičkog proizvoda. U tri od ukupno četiri uzorka koji su sadržavali soj L. rhamnosus Howaru HNOO1 ${ }^{\mathrm{TM}}$ sam ili u kombinaciji s drugim probiotičkim sojevima, broj živih stanica L. rhamnosus Howaru HNOO1 ${ }^{\mathrm{TM}}$ održao se na početnoj inokuliranoj razini, dok se značajno povećao u ko-kulturi s L. acidophilus 74-2. Uzimajući u obzir ukupna senzorska svojstva i preživljavanje probiotika, Cacık s dodatkom pojedinačnih sojeva L. rhamnosus Howaru HNO01 ${ }^{\text {TM }}$ ili B. longum BB536 i L. rhamnosus Howaru HN001 ${ }^{\text {TM }}$ ili L. acidophilus 74-2 i L. rhamnosus Howaru HNOO1 ${ }^{\mathrm{TM}}$ ili sva tri probiotika može se smatrati pogodnim za daljnju proizvodnju.

\section{Ključne riječi: probiotik, preživljavanje, interakcija, predjelo na bazi jogurta, aditivi}


1. Ahlroos, T., Tynkkynen, S. (2009): Quantitative strain-specific detection of Lactobacillus rhamnosus GG in human faecal samples by real-time pcr. Journal of Applied Microbiology 106 (2), 506-514. https://doi.org/10.1111/j.1365-2672.2008.04018.x

2. Altuntas, S., Korukluoglu, M. (2019): Growth and effect of garlic (Allium sativum) on selected beneficial bacteria. Food Science and Technology 39 (2). https://doi.org/10.1590/fst.10618

3. Champagne, C., Green-Johnson, J., Raymond, Y., Barrette, J., Buckley, N. (2009): Selection of probiotic bacteria for the fermentation of a soy beverage in combination with Streptococcus thermophilus. Food Research International 42 (5-6), 612-621. https://doi.org/10.1016/j.foodres.2008.12.018

4. Champagne, C.P., Gardner, N.J., Roy, D. (2005): Challenges in the addition of probiotic cultures to foods. Critical Reviews in Food Science and Nutrition 45 (1), 61-84. https://doi.org/10.1080/10408690590900144

5. Chekroun, A., Bensoltane, A., Kheroua, O., Saidi, D. (2006): Biotechnological characteristics of fermented milk by bacterial associations of the strains Streptococcus, Lactobacillus and Bifidobacterium. Egyptian Journal of Applied Sciences 21 (2b), 583-598.

6. Dave, R.I. (1998): Factors affecting viability of yoghurt and probiotic bacteria in commercial starter cultures (PhD thesis). Australia: Centre for Bioprocessing and Food Technology, School of Life Sciences and Technology Victoria University of Technology.

7. Donkor, O., Henriksson, A., Vasiljevic, T., Shah, N. (2006): Effect of acidification on the activity of probiotics in yoghurt during cold storage. International Dairy Journal 16 (10), 1181-1189. https://doi.org/10.1016/j.idairyj.2005.10.008

8. Evans, J. D. (1996): Straightforward statistics for the behavioral sciences. Brooks/Cole Pub Co.

9. Farnsworth, J.P., Li, J., Hendricks, G.M., Guo, M.R. (2006): Effects of transglutaminase treatment on functional properties and probiotic culture survivability of goat milk yogurt. Small Ruminant Research 65 (1-2), 113-121. https://doi.org/10.1016/j.smallrumres.2005.05.036

10. Ferdousi, R., Rouhi, M., Mohammadi, R., Mortazavian, A.M., Khosravi-Darani, K., Rad, A.H. (2013): Evaluation of probiotic survivability in yogurt exposed to cold chain interruption. Iranian Journal of Pharmaceutical Research 12 (Suppl), 139144.

11. Hekmat, S., Soltani, H., Reid, G. (2009): Growth and survival of Lactobacillus reuteri RC-14 and Lactobacillus rhamnosus GR-1 in yogurt for use as a functional food. Innovative food science \& emerging technologies 10 (2), 293-296. https://doi.org/10.1016/j.ifset.2008.10.007

12. Isanga, J., Zhang, G. (2009): Production and evaluation of some physicochemical parameters of peanut milk yoghurt. LWT-Food Science and Technology 42 (6), 1132-1138. https://doi.org/10.1016/j.lwt.2009.01.014

13. ISO/IDF. (2005): Yogurt - determination of total solids content (reference method), IDF bulletin No 151. Brussels, Belgium: International Dairy Federation.
14. ISO/IDF. (2009): Milk and milk products - determination of fat content - general guidance on the use of butyrometric methods. IDF bulletin No 152. Brussels, Belgium: International Dairy Federation. https://doi.org/10.3403/30200361

15. ISO/IDF. (2014): Milk and milk products - determination of nitrogen content - part 1: Kjeldahl principle and crude protein calculation. IDF bulletin $N^{\circ} 20-1$. Brussels, Belgium: International Dairy Federation. https://doi.org/10.3403/30258435

16. ISO/IDF. (2008): Milk - determination of fat content. IDF bulletin $N^{\circ}$ 226. Brussels, Belgium: International Dairy Federation.

17. Kailasapathy, K., Harmstorf, I., Phillips, M. (2008): Survival of Lactobacillus acidophilus and Bifidobacterium animalis ssp. lactis in stirred fruit yogurts. LWT-Food Science and Technology 41 (7), 1317-1322. https://doi.org/10.1016/j.lwt.2007.08.009

18. Klu, Y.A.K., Williams, J.H., Phillips, R.D., Chen, J. (2012): Survival of Lactobacillus rhamnosus GG as influenced by storage conditions and product matrixes. Journal of Food Science 77 (12), M659-M663. https://doi.org/10.1111/j.1750-3841.2012.02969.x

19. Kos, B., Beganović, J., Jurašić, L., Švađumović, M., Leboš Pavunc, A., Uroić, K., Šušković, J. (2011): Coculture-inducible bacteriocin biosynthesis of different probiotic strains by dairy starter culture Lactococcus lactis. Mljekarstvo 61 (4), 273-282. https://doi.org/10.1016/j.micres.2013.09.015

20. Kucukoner, E., Tarakci, Z., Sagdic, O. (2006): Physicochemical and microbiological characteristics and mineral content of herby cacik, a traditional Turkish dairy product. Journal of the Science of Food and Agriculture 86 (2), 333-338. https://doi.org/10.1002/jsfa.2265

21. Laterza, L., Gibiino, G., Scaldaferri, F., Gasbarrini, A. (2018): Benefits of multistrain bacteria formulations for health. Journal of functional foods 47, 531-546. https://doi.org/10.1016/j.jff.2018.05.051

22. Leboš Pavunc, A., Kos, B., Beganović, J., Uroić, K., Bučan, D., Šušković, J. (2013): Antibiotic susceptibility and antimicrobial activity of autochthonous starter cultures as safety parameters for fresh cheese production. Mljekarstvo 63 (4), 185-194. https://doi.org/10.1016/j.micres.2013.09.015

23. Li, S., Walsh, H., Gokavi, S., Guo, M. (2012): Interactions between Lactobacillus acidophilus strains and the starter cultures, Lactobacillus bulgaricus and Streptococcus thermophilus during fermentation of goats milk. African Journal of Biotechnology 11 (51), 11271-11279. https://doi.org/10.5897/ajb12.496

24. Lourens-Hattingh, A., Viljoen, B.C. (2001): Yogurt as probiotic carrier food. International Dairy Journal 11 (1-2), 1-17. https://doi.org/10.1016/s0958-6946(01)00036-x

25. Magalhães, R., Ferreira, V., Brandão, T. R., Palencia, R.C., Almeida, G., Teixeira, P. (2016): Persistent and non-persistent strains of Listeria monocytogenes: A focus on growth kinetics under different temperature, salt, and $\mathrm{pH}$ conditions and their sensitivity to sanitizers. Food Microbiology 57, 103-108. https://doi.org/10.1016/j.fm.2016.02.005 
26. Mahmoudi, F., Miloud, H., Bettache, G., Mebrouk, K. (2013): Identification and physiological properties of bifidobacterium strains isolated from different origin. Journal of Food Science and Engineering 3 (4), 196-206. https://doi.org/10.17265/2159-5828/2012.10.005

27. Mani-López, E., Palou, E., López-Malo, A. (2014): Probiotic viability and storage stability of yogurts and fermented milks prepared with several mixtures of lactic acid bacteria. Journal of Dairy Science 97 (5), 2578-2590. https://doi.org/10.3168/jds.2013-7551

28. Michael, M., Phebus, R.K., Schmidt, K.A. (2015): Plant extract enhances the viability of Lactobacillus delbrueckii subsp. bulgaricus and Lactobacillus acidophilus in probiotic nonfat yogurt. Food Science and Nutrition 3 (1), 48-55. https://doi.org/10.1002/fsn3.189

29. Mohammadi, R., Sohrabvandi, S., Mohammad Mortazavian, A. (2012): The starter culture characteristics of probiotic microorganisms in fermented milks. Engineering in Life Sciences 12 (4), 399-409. https://doi.org/10.1002/elsc.201100125

30. Ng, E.W., Yeung, M., Tong, P.S. (2011): Effects of yogurt starter cultures on the survival of Lactobacillus acidophilus. International Journal of Food Microbiology 145 (1), 169-175. https://doi.org/10.1016/j.jffoodmicro.2010.12.006

31. Olson, D., Aryana, K. (2008): An excessively high lactobacillus acidophilus inoculation level in yogurt lowers product quality during storage. LWT-Food Science and Technology 41 (5), 911-918. https://doi.org/10.1016/j.lwt.2007.05.017

32. Ozturk, H.I., Demirci, T., Akın, N. (2017): Production of functional probiotic ice creams with white and dark blue fruits of Myrtus communis: The comparison of the prebiotic potentials on Lactobacillus casei 431 and functional characteristics. LWT-Food Science and Technology 90, 339345. https://doi.org/10.1016/j.lwt.2017.12.049

33. Rutella, G.S., Tagliazucchi, D., Solieri, L. (2016): Survival and bioactivities of selected probiotic lactobacilli in yogurt fermentation and cold storage: New insights for developing a bi-functional dairy food. Food Microbiology 60, 54-61. https://doi.org/10.1016/j.fm.2016.06.017

34. Saccaro, D.M., Tamime, A.Y., Pilleggi, A.L.O., Oliveira, M.N. (2009): The viability of three probiotic organisms grown with yoghurt starter cultures during storage for 21 days at $4 \mathrm{C}$. International Journal of Dairy Technology 62 (3), 397-404. https://doi.org/10.1111/j.1471-0307.2009.00497.x

35. Settachaimongkon, S., Nout, M.R., Fernandes, E.C.A., van Hooijdonk, T.C., Zwietering, M.H., Smid, E.J., van Valenberg, H.J. (2014) The impact of selected strains of probiotic bacteria on metabolite: formation in set yoghurt. International Dairy Journal 38 (1), 1-10. https://doi.org/10.1016/j.idairyj.2014.04.002

36. Shah, N.P. (2007): Functional cultures and health benefits. International Dairy Journal 17 (11), 1262- 1277.

37. Sodini, I., Lucas, A., Oliveira, M. N., Remeuf, F., Corrieu, G. (2002): Effect of milk base and starter culture on acidification, texture, and probiotic cell counts in fermented milk processing. Journal of Dairy Science 85 (10), 2479-2488. https://doi.org/10.3168/jds.s0022-0302(02)74330-0
38. Tharmaraj, N., Shah, N.P. (2003): Selective enumeration of Lactobacillus delbrueckii ssp. bulgaricus, Streptococcus thermophilus, Lactobacillus acidophilus, bifidobacteria, Lactobacillus casei, Lactobacillus rhamnosus, and propionibacteria. Journal of Dairy Science 86 (7), 2288-2296. https://doi.org/10.3168/jds.s0022-0302(03)73821-1

39. Tharmaraj, N., Shah, N.P. (2004): Survival of Lactobacillus acidophilus, Lactobacillus paracasei subsp. paracasei, Lactobacillus rhamnosus, Bifidobacterium animalis and Propionibacterium in cheese-based dips and the suitability of dips as effective carriers of probiotic bacteria. International Dairy Journal 14 (12), 1055-1066. https://doi.org/10.1016/j.idairyj.2004.04.011

40. Tsiraki, M.I., Savvaidis, I.N. (2014): Citrus extract or natamycin treatments on tzatziki - a traditional Greek salad. Food chemistry 142, 416-422. https://doi.org/10.1016/j.foodchem.2013.07.087

41. Turgut, T., Cakmakci, S. (2018): Probiotic strawberry yogurts: microbiological, chemical and sensory properties. Probiotics and antimicrobial proteins 10 (1), 64-70. https://doi.org/10.1007/s12602-017-9278-6

42. Vargas, M., Cháfer, M., Albors, A., Chiralt, A., GonzálezMartínez, C. (2008): Physicochemical and sensory characteristics of yoghurt produced from mixtures of cows' and goats' milk. International Dairy Journal 18 (12), 1146 1152. https://doi.org/10.1016/j.idairyj.2008.06.007

43. Vinderola, C., Costa, G., Regenhardt, S., Reinheimer, J. (2002a): Influence of compounds associated with fermented dairy products on the growth of lactic acid starter and probiotic bacteria. International Dairy Journal 12 (7), 579-589. https://doi.org/10.1016/s0958-6946(02)00046-8

44. Vinderola, C., Mocchiutti, P., Reinheimer, J. (2002b): Interactions among lactic acid starter and probiotic bacteria used for fermented dairy products. Journal of Dairy Science 85 (4), 721-729. https://doi.org/10.3168/jds.s0022-0302(02)74129-5

45. Wang, YC, Yu, RC, Yang, HY, Chou, CC. (2005): Sugar and acid contents in soymilk. International Dairy Journal 15, 439-448.

46. Yilmaz-Ersan, L., Kurdal, E. (2014): The production of set-type-bio-yoghurt with commercial probiotic culture. International Journal of Chemical Engineering and Applications 5 (5), 402-408. https://doi.org/10.7763/ijcea.2014.v5.418

47. Zacarchenco, P. B., Massaguer-Roig, S. (2006): Properties of Streptococcus thermophilus fermented milk containing variable concentrations of Bifidobacterium longum and Lactobacillus acidophilus. Brazilian Journal of Microbiology 37 (3), 338-344. https://doi.org/10.1590/s1517-83822006000300025

48. Zhang, N., Huang, X., Zeng, Y., Wu, X., Peng, X. (2013): Study on prebiotic effectiveness of neutral garlic fructan in vitro. Food Science and Human Wellness 2 (3-4), 119-123. https://doi.org/10.1016/j.fshw.2013.07.001 